\title{
Da liberdade em literatura: \\ seu alcance ético e filosófico
}

\author{
Of freedom in literature: \\ its ethical and philosophical reach
}

Marcelo Peloggio*

\begin{abstract}
RESUMO: O texto procura mostrar, pela perspectiva literária, o alcance ético e filosófico do conceito de liberdade, partindo do princípio de que só é possível pensá-lo à luz da não liberdade. Dessa forma, a liberdade é considerada como algo a ser negociado no âmbito das relações sociais, o que leva a negar a sua natureza absoluta como um princípio excelso e definitivo. Tal fato confirma o seu caráter dialético enquanto uma faculdade crítica, sem qualquer relação com a ideia de solidão, pois esta, de modo equivocado, advoga a noção de uma liberdade sem limites de uma personalidade autossuficiente e voltada sobre si mesma.
\end{abstract}

PALAVRAS-CHAVE: literatura; ética; solidão; liberdade.

ABSTRACT: This paper intends to present the ethical and philosophical scope of the concept of freedom from a literary perspective, considering the only possibility of thinking this concept in the light of negation of freedom itself. In this way, freedom is considered something to be negotiated within the framework of social relations, which leads to deny its absolute nature, as a supreme and definitive principle. This confirms its dialectical character as a critical faculty, unrelated to the idea of solitude, for it wrongly advocates the notion of boundless freedom from a self-sufficient, self-centered personality.

KEYWORDS: literature; ethics; solitude; freedom.

* Professor Associado de Literatura Brasileira na Universidade Federal do Ceará, doutor em Literatura Comparada pela Universidade Federal Fluminense. E-mail: peloggio@hotmail.com. ORCID: http://orcid.org/oooo-0002-1789-9695. 
Por liberdade, então, só podemos querer significar um poder de agir ou não agir; conforme as determinações da vontade. (HUME, 2009, p. 144)

É do conhecimento de todos, mas nunca é demais enfatizar: a liberdade não é aquilo que se deve conceber como algo absoluto; daí a importância de seu alcance em um dado espaço de atuação, isto é, restringindo-se a esse ou àquele domínio e não mais do que isso. Mas é justamente aí que a liberdade ganha ares de coisa sagrada, intentio legis, evocada por uma infinidade de grupos como ferramenta de denúncia, a indicar o cerceamento impingido por forças que lhes seriam contrárias ou hostis. Grupos esses que reclamam mais liberdade, e que a julgam ameaçada pela beligerância vinda "de fora". A máxima "A minha liberdade termina quando começa a do outro" não tem, para o caso, o efeito de um valor propositivo ou ético: porque ao outro é negada, como que para sempre, o resgate dessa suposta liberdade que haveria "cedido". A liberdade, sob essa perspectiva, apresenta-se sob duas formas bem distintas: ora como uma mera noção teórica (algo excelso, direito que deve estar ao alcance de todos); ora em seu uso indiscriminado (ou antes, a liberdade "irrestrita" de quem concede uma liberdade restritíssima).

O termo liberdade confunde-se, na maior parte das vezes, com a porção semântica de sua história, isto é, na qualidade de um conceito formulado a partir de sentimentos, ideias, afecções e assim por diante. Mas o que conta, de fato, é a capacidade de todos e cada um de "agir conforme a própria vontade" e, claro, sempre em acordo com as leis e normas que, racionalmente estabelecidas, regem a vida de relação. Vico (1979, p. 81), em sua Ciência nova, nos fala de uma "autoridade humana", nos primórdios da civilização mundial, a designar "o livre uso da vontade", celebrando, por essa via, "a liberdade que tinha o humano arbítrio de frear os impulsos dos corpos”. Pode-se dizer, portanto, que, mais do que propriamente um conceito, ideal ou expectativa, a liberdade não é senão, pois, uma faculdade.

Seu uso dependerá, então, de uma série de fatores: que vão do lugar de sua articulação e operacionalidade (portanto, a sua permissividade) até, o que é óbvio, a iniciativa de quem decide lançar mão da própria liberdade. Em todo caso, 


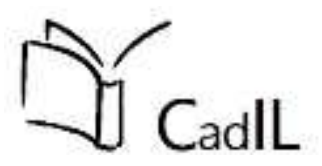

a liberdade só pode configurar-se mediante aquilo que, em grupo ou isoladamente, haveremos de sancionar em um momento qualquer. No segundo caso, ou antes de maneira isolada, sirva de exemplo a decisão que Julien Sorel toma, em $O$ vermelho e o negro, por conta e risco do próprio alvitre, ou seja, assassinar a sua ex-amante, a sra. de Rênal: "Julien não a reconhecia mais tão bem; atirou uma vez e errou; atirou um segunda vez, ela caiu" (STENDHAL, 2015, p. 457). No polo oposto, teremos a anuência coletiva, a fim de tornar-se efetivo o instrumento por definição da vontade, a liberdade. É o que mostra esta passagem da Ilíada:

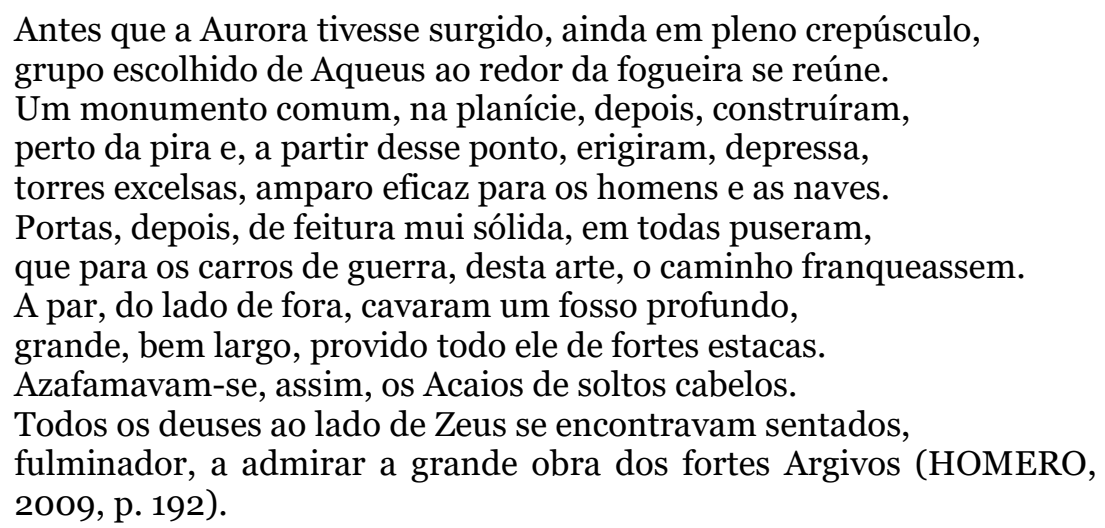

Mas o regime das liberdades não é algo de tão fácil determinação e apreensão como podem sugerir os nossos exemplos. Há casos em que a própria luta pela liberdade - por razões de natureza ideológica, ou mesmo pessoal dificulta, impede ou recrimina o querer dizer ou fazer em nada discrepante a uma decisão primeira: a preservação das liberdades democráticas. Assim, em colóquio particular, dois sujeitos se mostram descontentes com o grupo político de que fazem parte; e um deles é desafiado a expor à sua grei algumas ideias que, do seu ponto de vista, mostrar-se-iam bastante satisfatórias; de pronto, responde com um pavor surdo: “Jamais!”. O que é uma contradição em termos: não pelo fato de ter como certa a desaprovação dos demais membros, mas por impedir-se a si próprio à apresentação de opiniões críticas e problematizadoras - talvez em função do desdobramento da reprimenda - em um ambiente que teria por invioláveis, em princípio, a liberdade de expressão e as garantias individuais. 
A liberdade pode ser concebida, à luz dos anedotários, como o privilégio e instrumento dos que decidem (coletiva ou individualmente) quem dela pode fazer uso ou participar, de onde se segue que o alcance de uma vontade depende, em muitos casos, recordando aqui Esopo (2013, p. 27) 1 , de saber "melhor ceder às circunstâncias e aos mais fortes que rivalizar com os poderosos”. A liberdade, aí e então, mais se assemelha a um risco calculado do que a algo propriamente consentido; por isso, a sentença de La Rochefoucauld (2014, p. 60): com efeito, “nossas ações são como rimas forçadas, que cada um aplica ao que lhe agrada”. E é sob esse princípio que nossa liberdade parece não conhecer qualquer obstáculo ou interdição: haveria nela um quer que seja de inaudito e, por conseguinte, de superior.

Ora, a liberdade é uma mesma e única coisa (se tomada então em sua efetividade concreta), e, assim sendo, nada mais a propósito quando a denominamos liberdade em geral. No entanto, são tantas e tais as especificidades da expressão que não raro olvidamos o fato de a liberdade, via de regra, ser regida precisamente por aquilo que a constrange ou a procura eliminar, a saber, a não liberdade (impedimentos, ameaças, privações - agentes esses que passam do exterior mundano ou empírico para o âmbito espiritual).

No mais, é a liberdade, em uma acepção simples, a faculdade de que dispomos para nos autodeterminar, quando então nos resolvemos a algo com o fim de satisfazer, mediata ou imediatamente, nossa vontade; em outras palavras, diz Brugger (1977, p. 247), designa “o não estar preso de maneira nenhuma, o estar isento de travas".

Por certo, a presença de alguém em lugares ermos, como florestas, serras, montes, picos, cavernas eremíticas, montanhas, quer dizer, em um estado de total solidão, costuma despertar-nos na alma a noção romântica de liberdade - o que imprime nos misantropos, dependendo do caso, um ar saturado da mais pura melancolia, terror ou fervor místico: Humbaba, Doroteia, o Homem da Colina,

\footnotetext{
${ }^{1}$ Vale registrar aqui a fala de Diógenes, referida pelo padre Antônio Vieira (1974, p. 134): "Diógenes, que tudo via com mais aguda vista que os outros homens, viu que uma grande tropa de varas e ministros de justiça levavam a enforcar uns ladrões, e começou a bradar: 'Lá vão os ladrões grandes enforcar os pequenos"”.
} 
Werther, o padre Aubry, Aires de Lucena, Jean-Baptiste Grenouille, entre outros, são exemplos típicos do que falamos².

O que não passa de um equívoco ou puro ardil, já que ninguém dispõe totalmente de si o tempo todo, de vez que, na outra ponta, se acha, não raro, o outro. É o que confirma a seguinte passagem de Robinson Crusoé, de Defoe (1972, p. 17): “- Nade para a costa - disse-lhe [ao indivíduo que havia lançado na água] -, que o mar está calmo. Se tentar se aproximar, meto-lhe um tiro na cabeça”.

Não sendo, portanto, um dado absoluto, ou algo como um objeto natural, não se tem por que medir o real valor de seu alcance e significado senão à luz dos mecanismos que, a todo momento, a obliteram. De onde se segue que não é possível a liberdade sem que haja, em primeiro lugar, os meios através do quais se dá a sua elisão parcial ou quase que completa; porque não há ausência total de liberdade. Fosse o caso, os instrumentos próprios ao cerceamento, repressão e controle se dissipariam no ar. Daí que só é possível avaliar o grau de nossa liberdade - e isso de modo claro e efetivo - à medida que somos apartados de seus setores; ou antes, quando o acesso a seus domínios nos vai sendo negado, pouco e pouco, de forma veemente; isto é, a liberdade só pode ser realmente considerada a partir daquilo que a nega para, ao mesmo tempo, afirmá-la com ênfase e destemor.

Tal fato não se constata apenas, digamos, fisicamente. Porque os impedimentos, interditos, supressões, ou coisa que os valha, podem também ser sugestionados, e assim a chamada "falta de liberdade" parece nos corroer por dentro, dando vez e lugar a um abatimento moral que, não raro, paralisa, ou, por que não dizer, oprime, acorrentando nossas faculdades. Nada nos impede de ir e vir, e isso, claro, dentro dos limites da liberdade que nos foi concedida. E há casos curiosos em que sua falta acomete grupos inteiros em razão da simples presença de um único indivíduo, como exemplifica à perfeição a novela Uma história lamentável3, de Dostoiévski (1996). Assim, um jovem general, Iván Ilítch,

\footnotetext{
2 Respectivamente, personagens de a Epopeia de Gilgámesh (SIN-LÉQI-UNNÍNNI, 2018), Dom Quixote (SAAVEDRA, 2002), Tom Jones (FIELDING, 2003), Werther (GOETHE, 2002), Atala (CHATEAUBRIAND, 1972), O ermitão da Glória (ALENCAR, 1951a) e O perfume (SÜSKIND, [s.d.]).

3 Traduzida também por Uma anedota infame.
} 
tomado pelo fervor de uma visão humanitária, e imbuído de pôr em prática seus ideais reformadores, encontra a ocasião para visitar, sem aviso, a casa de um subalterno, Pseldonímov, que celebrava núpcias. A presença inesperada do militar - e este querendo parecer natural, dispensando as formalidades que sua posição exigia - fez do evento algo pesaroso, carregado de desconfiança, constrangendo os convidados até o ponto da desavença. A celebração, já de si bastante modesta, tornou-se onerosa aos anfitriões, de vez que Iván Ilítch lhes sorveu as duas únicas garrafas de champanha. Este, ao fim e ao cabo, se embebeda, desmaia e é conduzido, então, ao leito de núpcias, por conta de um desarranjo intestinal, o que o faz ficar sob os cuidados da mãe de Pseldonímov. Deixa a casa após oito dias.

Por outro lado, o sentimento de falta de liberdade pode ser despertado em um ou vários indivíduos por intermédio de um grupo de pessoas. Falamos mais precisamente da sensação incômoda de não se sentir bem-vindo ou como que parte integrante de um dado ambiente. O exemplo pode ser colhido desta outra passagem de $O$ vermelho e o negro:

\footnotetext{
A infelicidade diminui a presença de espírito. Nosso herói [Julien Sorel] teve a triste ideia de parar junto àquela cadeirinha de palha, que testemunhara outrora tão brilhantes triunfos. Nesse dia, ninguém lhe dirigiu a palavra; sua presença passava despercebida ou coisa pior. Os amigos da srta. de La Mole, aqueles que estavam perto dele, na extremidade do canapé, procuravam de alguma forma dar-lhe as costas, ou, pelo menos, foi o que lhe passou pela cabeça (STENDHAL, 2015, p. $370)$.
}

A liberdade pode se ver cerceada, na condição de uma faculdade efetiva, sem que se lance mão da exterioridade concreta, isto é, da força bruta. De fato, via "presença de espírito", ora dilatando-se, ora comprimindo-se, é possível aferir, com alguma precisão, o impacto psicológico resultante de um acontecimento qualquer (político, social, religioso, científico etc.).

Ora, a liberdade (não a liberdade em si, mas aquela de todos os dias) não constitui algo que pura e simplesmente toldamos ou silenciamos com o uso de instrumentos físicos de repressão, intimidação ou cerceamento. Esse modus operandi vai mais longe, já que é sutilíssimo, e acarreta, por isso mesmo, efeitos devastadores. Emprega-se, pois, para a inibição do querer, uma série de 


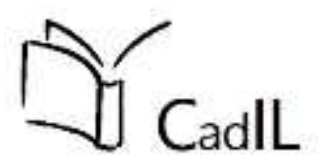

expedientes, recursos, mecanismos, compondo, assim, todo um arsenal à nossa inteira disposição: o gestuário, o sentido das palavras e o tom da voz, o olhar e, mesmo, a presença intimidadora do silêncio. Podemos dizer que o uso da liberdade só se justifica à luz de um poder real (físico e sobretudo espiritual) que se lhe oponha, a ponto mesmo de censurá-lo ou coibi-lo enquanto sua não liberdade.

Tomemos um exemplo. No romance histórico de José de Alencar - As minas de prata -, a expectativa de uma ação certa, livre de qualquer embraço, por parte do visitador inaciano, Gusmão de Molina (que tenta a posse de um tesouro lendário), vê-se frustrada pelo herói do drama, Estácio Dias Correia, de sorte que este o imobiliza sem o uso dos braços, mas tão somente com a força do olhar:

Estácio [...] ia empurrando a porta [...]; apenas dentro, ganhara ele o quintal, penetrara em casa do fidalgo; e foi guiado ao seu gabinete pela velha caseira, que subia de espanto em espanto.

$\mathrm{O}$ mancebo circulou o aposento com um olhar rápido, que afinal foi cravar-se na fisionomia do jesuíta; este já havia dominado o seu primeiro pasmo, e impassível abaixava a vista para o papel onde continuava a escrever (ALENCAR, 1951b, p. 723).

Episódios como esse parecem poder determinar o real alcance da liberdade, fornecer sua medida em graus, ou antes, os motivos pelos quais ela se enregela ou é capaz, pelo contrário, de incendiar o ânimo mesmo:

\footnotetext{
Alça-te, filho do claro Peleu [Aquiles], dos heróis o mais forte; corre em defesa de Pátroclo, em torno do qual, junto às naves, pugna terrível se ateou; uns aos outros, ali, se trucidam; de um lado, os fortes Aqueus, desejosos de o corpo [de Pátroclo] trazerte, do outro, os Dardânios, que o querem levar para os muros de Troia (HOMERO, 2009, 416).
}

Todavia, Rousseau (2010, p. 10) a fez parte constituinte do sentimento de solidão. Flanando por Paris e arredores, ocupado de suas reflexões e observações gerais, declara: "sou cem vezes mais feliz em minha solidão do que poderia ser vivendo com eles", quer dizer, em meio aos demais homens.

Esse modo de encarar a realidade a partir do autoexílio, sob a perspectiva redentora de que o refúgio interior, nessa condição, pode ser finalmente 
explorado com total liberdade, possibilitando o autoconhecimento, o encontro do $e u$ consigo próprio, transformou este último na única realidade possível, substancial, verdadeira, já que autossuficiente. Tal procedimento desembocaria naquilo que Hegel (2001, p. 83) denominou "interioridade insatisfeita e abstrata" e, por extensão, no "mau infinito", em que os termos do par conceito-realidade são suplantados de maneira equívoca pela extravagância ou unilateralidade de algumas posturas ou concepções, a exemplo do Eu absoluto fichteano. Porque, para Fichte (1981, p. 309, grifo do autor), antes do mais, "liberdade significa: não há natureza acima da vontade, esta é sua única criadora possível”. Enfim, para o autor de A doutrina da ciência, o Eu é "liberdade infinita, pura, absoluta" (BORNHEIM, 2008, p. 93). “A posição radical de Fichte nos diz então que, se quisermos defender a liberdade, precisamos negar o mundo exterior" (BORNHEIM, 2008, p. 88). Em todo caso, ainda que postule um "reino dos espíritos" ou a existência das demais "consciências individuais", o idealismo fichteano parece criar as condições teóricas necessárias para uma mudança de curso e, então, por mais que se afaste, culminar, pelo contrário, no solipsismo.

O solipsismo, em que o eu toma-se a si próprio como a medida de todas as coisas, tem no princípio berkeleyano esse est percipi (“ser é ser percebido”), a base de sua sistematização filosófica e o meio mais seguro para os diversos graus de exageração dessa doutrina em suas derivações (o panteísmo anímico, por exemplo). Nesse caso, o outro só tem existência se essa lhe for conferida/concedida por mim, de vez que, sob o meu campo de visão, eu $o$ percebi. Nada do que existe no mundo - uma cadeira, uma nódoa de tinta azul, um casal de canários, qualquer um de nós -, diz Berkeley (2010, p. 61), "não [possui] nenhuma existência fora de uma mente”. E acrescenta:

na medida em que eles [os objetos] não são de fato percebidos por mim, ou não existem na minha mente ou na de qualquer outro espírito criado, não devem ter absolutamente existência alguma (BERKELEY, 2010, p. $61)$.

É o idealismo empírico de Berkeley (2010), seu imaterialismo de fundo anímico, algo que encontra eco em uma realidade mudada nas manifestações do Eu puro fichteano; enfim, expressões de um determinismo subjetivista, que, em 
rigor, isola o eu do mundo sensível ou, muito pelo contrário, transforma este na expressão de infinitude daquele: “Aos homens nada é impossível: eu posso aquilo que quero”, diz Novalis (ABBAGNANO, 1984, p. 171); e conforme a sugestão de Blake (2011, p. 85): “Segura o infinito em sua mão/E a eternidade num segundo”. Confundir-se com tudo à volta ou simplesmente negar a exterioridade e seus fenômenos e aplicar-se ao conhecimento de si, suplantando assim a natureza pelo simples fato de poder determiná-la:

De que nos deleitamos em semelhante situação? De nada exterior a nós mesmos, de nada além de nós mesmos e de nossa própria existência; enquanto esse estado dura, bastamos a nós mesmos como Deus (ROUSSEAU, 2010, p. 70).

Mas o eu não pode ir tão longe ou tão fundo: ali, repousando em si mesmo e negando-se a agir, pois o mundo se lhe afigura degenerado, inessencial, pela ausência de objetos que sejam perfeitamente adequados a esse eu; aqui, julgandose o porta-voz de uma idealidade moral e artística superior, como expressão de uma potência infinita e criadora, a ser cultivada, então, por meio de nossa atividade espiritual. Com esta, portanto, a possibilidade viva de integração com o Absoluto, nas linhas do Hen kai Pan (o Uno e o Todo), tal como o professa Hölderlin, com candura lírica, no Hipérion:

\footnotetext{
Unir-se ao todo é a vida divina, é o céu do homem.

Unir-se a tudo o que vive, regressar ao todo da Natureza, em feliz esquecimento próprio, é o mais elevado pensamento e a maior das alegrias, é o sagrado cume do monte, o lugar de eterno descanso, onde o meio-dia perde o seu ar abafado e o trovão a sua voz e o mar embravecido se assemelha à ondulação dos campos de trigo.

Unir-se a tudo o que vive! [...] perante a imagem do mundo eternamente uno (HÖLDERLIN, 1997, p. 23).
}

O curioso em tudo isso não é o fato de ser Hipérion, de resto, um eremita, fruto de uma imaginação nostálgica e luxuriante, própria dos "românticos do sentimento": a creditamos, com efeito, a uma linha aberta por Rousseau (2010), que diz ter conhecido na solidão a felicidade que não pôde encontrar junto aos homens. Solidão essa que, sob o nosso ponto de vista, se conjuga, equivocamente, com o conceito de liberdade. E isso por dois motivos, a saber: ainda que o sentimento de solidão possa parecer fundamental à liberdade, o caminho inverso 
nem sempre é possível ou viável e, mesmo, desejável. Porque só se pode desfrutar a solidão em sociedade, mesmo para quem se julga completamente só. Isolar-se de tudo e todos; cultivar por inciativa própria a antropofobia, como fez o autor das Confissões, só têm justificativa, significação e, claro, real valor se o propósito não for outro senão aquele de Os devaneios: o flanador solitário conhecendo-se a si próprio - o que quer dizer, de antemão, a humanidade toda que o habita por inteiro. Assim, refugiado em si mesmo, sopesa a sociedade, nos círculos do pensamento ético e sua ação correspondente:

\begin{abstract}
Tantas experiências cruéis aos poucos mudaram minhas disposições originais, ou melhor, por fim encerrando-as em seus verdadeiros limites, me ensinaram a seguir de maneira menos cega minha inclinação para a caridade, que servia apenas para facilitar a maldade alheia.

Mas não lamento essas mesmas experiências, pois me proporcionaram, através da reflexão, novas luzes sobre o conhecimento de mim mesmo e sobre os verdadeiros motivos de minha conduta em mil circunstâncias sobre as quais com frequência me iludi. Vi que para fazer o bem com prazer seria preciso agir com liberdade, sem coação, e que para perder toda a doçura de uma boa ação bastaria que ela se tornasse um dever (ROUSSEAU, 2010, p. 77).
\end{abstract}

O que reforça o nosso entendimento de que a liberdade não deve ser encarada, de forma alguma, como algo em si, isto quer dizer, absoluta, sem limites ou amarras, ainda que Kant (2017) tenha preconizado, a título de lei moral, a ideia de se perseguir o bem pelo bem, de vez que seria imperativo fazê-lo. "Livres", nos resolvemos, aqui e ali, a simplesmente agir ou não agir, seja por que motivo ou interesse for. E a literatura, com seu apuro estético-filosófico, pode então descortinar o panorama tão necessário a uma consideração humanizadora, integrativa e ética dessa expressão clara e imediata de nosso ego volitivo: a liberdade.

E daí a segunda razão para se tomar como equívoca a associação que se costuma fazer, e como que obrigatória, do estado de solidão com o fato de se pôr em prática uma decisão tomada. Dizíamos que a solitude não é algo que se deve medir, simplesmente, à luz de nossa misantropia; pelo contrário, seu alcance só pode ser avaliado no seio da coletividade, o que não quer dizer que a "repulsa ao convívio social" seja de todo descartada. 
Indagamos se é fundamental à liberdade, em dada circunstância, o senso de uma vida solitária. Mas: e o questionamento inverso? A solitude, como produto de uma autoimposição (de que dão mostra os personagens aqui mencionados: Doroteia, o Homem da Colina, Aires de Lucena etc.), exige, de fato, a solidão; o isolamento que daí nasce - tão caro às meditações rousseaunianas não guarda qualquer relação com o fato de se estar realmente só ou em companhia de outras pessoas, mesmo em se tratando de uma multidão: pois que a solitude é, toda ela, de natureza interior, daí a maior impressão de liberdade. Para o caso, O amanuense Belmiro, de Cyro dos Anjos (1975), nos fornece um exemplo bastante expressivo.

Belmiro, o protagonista, é arrastado por uma turba, que se põe a brincar o carnaval pelas ruas de Belo Horizonte. O amanuense diz ter bebido, tornando-se "presa de grande excitação", para entregar-se, logo em seguida, sem opor qualquer resistência, "àquela humanidade que [lhe] pareceu mais cansada que alegre” (ANJOS, 1975, p. 20). E arremata, ao adentrar o salão de um clube carnavalesco: "Lembra-me que homens e mulheres, a um de fundo, mãos postas nos quadris do que ia à frente, dançavam, encadeados, e entoavam os coros sensuais que descem do Morro. Eram cantigas bem tristes, que vinham da carne" (ANJOS, 1975, p. 20).

A dissonância ou o forte contraste criado entre o interior (digamos, pleno em seu recolhimento, voltado sobre si mesmo, apesar da "grande excitação") e o exterior (a expandir-se cegamente - "fui arrastado pelos acontecimentos", diz o amanuense) mostra-se muito bem demarcado.

Em sua solitude, tendo que lidar com a euforia infrene dos foliões, que o instam a cada instante, Belmiro se vê recolhido em pensamentos que despedem a mais funda tristeza, invadido por sentimentos nostálgicos e associações livres o que o leva a tomar uma desconhecida, em meio ao vai e vem dos foliões, pela encantadora Arabela, resultado de um "mito infantil". Tudo aí pode ser reduzido à visão merencória de um sujeito sem atrativos e desajeitado: o que Belmiro tem diante dos olhos designa, antes do mais, uma humanidade "cansada" e triste, ao modo das cantigas, "que vinham da carne".

Introspecção, contemplação, fluxos de consciência, dramas da mente, solilóquios - ora, o solipsismo tem o seu arsenal, suas modalidades ou formas de 
expressão; e a literatura os tem mostrado, de praxe, sob a égide de alguns misantropos: Hamlet, em sua escalada obsessiva para vingar o assassinato do pai; Bentinho, corroído pela ideia fixa do adultério; Luís da Silva, de Angústia, transformando a real consideração que fazia de si próprio - um “zé ninguém” em um egotismo extremo, e daí investir contra a vida do rival Julião Tavares; ou ainda Werther, que, em razão de sua interioridade rica e abrangente, destituída de um objeto exterior que se lhe equivalesse, mete uma bala na própria cabeça.

Esses são outros exemplos de misantropia em que a solitude como que assevera o alcance da liberdade, isto é, de acordo com o estado de ânimo dos caracteres. Em todo caso, tal alcance só pode ter por parâmetro crítico a sua inserção completa no quadro da vida social, e não ter por base ou princípio de determinação os delírios, as reflexões, as meditações, as cismas desses solitários por convicção. Mudança de perspectiva confirmada pelas palavras de Cnêmon, sem se perder de vista o dado opositivo e contrastante na conquista da liberdade:

\begin{abstract}
Meu único erro, na verdade, era crer que somente eu, entre todos os homens, podia bastar-se a mim mesmo, sem ter necessidade de ninguém; agora que eu vi que a vida pode acabar quando menos se espera, num instante, achei que estava errado pensando como até agora. É preciso ter perto da gente alguém que esteja pronto para nos socorrer. Mas qual o quê! A minha cabeça estava tão virada de tanto ver as pessoas viverem cada uma de um jeito, agindo por interesse, que eu não podia imaginar que pudesse haver alguém no mundo capaz de agir desinteressadamente, por simpatia com os seus semelhantes (MENANDRO, [s.d.], p. 124-125).
\end{abstract}

Daí rearticular os termos de nossa indagação inicial. Perguntávamos: é fundamental à liberdade, em dada circunstância, a ideia de uma vida solitária? Não seria o caso de inverter a pergunta? Para se viver solitariamente, seja em que circunstância for, faz-se realmente necessário o senso de liberdade?

A nosso ver, do ponto de vista da ética e da filosofia, tal questionamento foi enfrentado por Machado de Assis no conto $O$ espelho.

O que amplia ou "diminui a presença de espírito" - para fazer uso das palavras de Stendhal (2015) - não é tanto a ausência de liberdade, mas a de interlocutores para se conhecer o verdadeiro alcance desta. Em $O$ espelho, as adulações, a lembrança recorrente da nova condição de Jacobina (o posto de alferes), são repisadas primeiramente em âmbito social (entre parentes e amigos) 
e, depois, no seio da vida doméstica, com as cortesias e rapapés de tia Marcolina, do grupo de escravos e, a seguir, de mais ninguém. A presença do outro, que nos coloca diante da não liberdade, representa, sem mais, a negação mesma da solitude; é pois, então, o apanágio da “opinião pública”, ou aquilo que Machado denomina “Legião" (ASSIS, 2005, p. 222). Se, na solitude, o ato volitivo projetase, digamos, de dentro para fora, ou então gira incessantemente em torno de si mesmo, refém que é de devaneios ou atitudes contemplativas, na "alma interior" machadiana, que entende apenas do "exercício da patente", o movimento é diametralmente inverso: a volição exulta e se abastece das manifestações exageradas de elogio e apreço - projeções essas que se dão de fora para dentro, lançando o ego do incauto Jacobina em uma fantasia que lhe será deveras vexatória.

Pode-se dizer que a solidão nunca foi tão malquista à luz da vida espiritual: a liberdade, em $O$ espelho, a partir de determinado ponto, não encontrará meios para se expandir e, de resto, atingir seus objetivos. Se, por um lado, para os adeptos da vida retirada, a solidão é condição sine qua non para o pleno gozo da liberdade (sobretudo interior - mas mesmo aí há limites), por outro, o isolamento de Jacobina se lhe torna adverso, motivo de sofrimento, mas de modo gradativo (inicialmente com a viagem de tia Marcolina e, depois, em maior grau, com a fuga dos escravos). Já com a partida daquela, argumenta o alferes:

Confesso-lhes que desde logo senti uma grande opressão, alguma cousa semelhante ao efeito de quatro paredes de um cárcere, subitamente levantadas em torno de mim. Era a alma exterior [o que ele entende compor e justificar sua "liberdade": a mera opinião alheia] que se reduzia (ASSIS, 2005, p. 226-227, grifos nossos).

A liberdade (a "presença de espírito") parece então encolher, definhar, à medida que a solidão vai tomando "proporções enormes"; o que arrefece o ato volitivo: "Tinha uma sensação inexplicável. Era como um defunto andando, um sonâmbulo, um boneco mecânico" (tudo que diz respeito a um determinismo cego, ou antes, à mais completa ausência de liberdade); e como reforço: "Tudo silêncio, um silêncio vasto, enorme, infinito" (ASSIS, 2005, p. 228-231).

Machado parece querer mostrar que, seja na vida solitária, seja na coletiva - evitando esta, vivenciando aquela -, o senso "pleno" de liberdade não passa de 
uma construção negociada, arbitrada, cujo verdadeiro alcance nasce da dialética entre a liberdade (no caso em questão, a de Jacobina, o elogiado) e sua não liberdade (a ausência ou presença de quem elogia: tia Marcolina, os escravos etc.).

Com Jacobina, ao contrário de Rousseau (2010), a solidão passa a ser o antípoda da liberdade, a simbolizar o regalo dos que conquistam ou ampliam o seu prestígio social. Liberdade, nesse caso, rima com soberba, o que não deixa sem razão a sentença de La Bruyère ([s.d.], p. 95): “O homem sensato evita às vezes o mundo, com medo de se aborrecer".

Mas ainda que o sentimento de solidão possa parecer fundamental à liberdade, nem sempre é desejável o caminho inverso aos que dependem da opinião do outro para ser: Jacobina de uniforme diante do espelho (afinal de contas, a "alma interior" é também social). De onde se segue que não há tipos de liberdade: um mais autêntico, outro menos; exercida por espíritos superiores ou arrivistas medíocres.

Com efeito, a liberdade é a faculdade mediante a qual o alcance dos nossos interesses tanto determina como é ao mesmo tempo determinado pelo alcance dos da coletividade em geral; por isso, a liberdade não é algo que se deva impor; em sentido particular, ela é, em muitos casos, negociada; em âmbito geral, é regulada ou definida por meio de dispositivos legais. Ela é a expressão da vontade coletiva, é bem verdade, mas, igualmente, de nossa decisão particular (seja no plano da política, das artes, da religião etc.).

Todavia, muito mais esclarecedoras do que as nossas são as palavras de Condorcet (2013, p. 125): “A conservação da liberdade depende da submissão à lei, que é a expressão da vontade geral”; ou ainda: "A liberdade consiste em poder fazer tudo que não é contrário aos direitos de outrem” (CONDORCET, 2013, p. 125).

Daí ter razão Graciliano Ramos (1984, p. 34): "Liberdade completa ninguém desfruta”. Mesmo na vida espiritual, em nosso desejo de querer ir sempre mais longe, a liberdade surge, então, envolta em dúvidas, esquecimentos e limitações de toda ordem que lhe atravancam o passo; e por mais que se apreenda, via intuição, a infinitude mesma, essa não passa da forma intelectual de um princípio configurador (a razão em Kant, por exemplo). 
Buscamos mostrar, neste ensaio, as formas de desdobramento da noção de liberdade em literatura. Vivenciada em grupo ou isoladamente, sua natureza individual e, a um tempo, coletiva só vem a esclarecer a importância do seu caráter humanizador, integrativo e ético. O que reforça a necessidade de se encará-la como um instrumento de reflexão poderosíssimo, fundamental e urgente em face do atual quadro de intransigência política, já que o sonho de todo e qualquer autoritário não é a ordem pelo arbítrio, mas a liberdade que desfrutará, em tese, sem qualquer limite. Daí que a liberdade nem é faculdade e nem muito menos um efeito de nosso ânimo; ela é a capacidade política que temos para assegurar o triunfo diário da ética sobre a moral, que aqui tomamos pelo que mostra ser: um valor meramente particular. Portanto, se as ideologias e sistemas de pensamento são passíveis de crítica significa que não passam de invenções muito bem construídas; pois a única coisa não inventada e necessária, é o direito de os formular em nome da ética. De onde se deve concluir que o problema não é a existência do que nos tolhe ou abate a liberdade (por um suposto determinismo), mas o que faremos com ela. Ou como diz ainda La Bruyère ([s.d.], p. 140): "um nobre, se vive na província, vive livre, mas sem apoio; se vive na corte, é protegido, mas é escravo: isso se compensa”.

O assustador avanço de visões e atitudes autoritárias leva a efeito imediato a depauperação das relações institucionais, pondo seriamente em risco o direito à liberdade (de expressão, de ir e vir, de pensamento, religiosa, artística e assim por diante) daqueles que se opõem ao que é imposto unilateralmente e à base da força bruta, ou seja, a liberdade absoluta da barbárie. 


\section{Referências}

ABBAGNANO, Nicola. História da filosofia. Lisboa: Editorial Presença, 1984. v. 8.

ALENCAR, José de. O garatuja, O ermitão da Glória e A alma do Lázaro. Rio de Janeiro: José Olympio, 1951a.

ALENCAR, José de. As minas de prata. Rio de Janeiro: José Olympio, 1951b. v. 3.

ANJOS, Cyro dos. O amanuense Belmiro. 8. ed. Rio de Janeiro: José Olympio, 1975 .

ASSIS, Joaquim Maria Machado de. O espelho. In: Papéis avulsos. São Paulo: Martins Fontes, 2005. p. 219-233.

BERKELEY, George. Obras filosóficas. São Paulo: UNESP, 2010.

BLAKE, William. O casamento do céu e do inferno \& outros escritos. Porto Alegre: L\&PM, 2011.

BORNHEIM, Gerd. Filosofia do romantismo. In: GUINSBURG, Jaime (org.). $O$ romantismo. São Paulo: Perspectiva, 2008. p. 75-111.

BRUGGER, Walter. Dicionário de Fïlosofia. 3. ed. São Paulo: EPU, 1977.

CHATEAUBRIAND, François-René de. Atala \& René. Lisboa: Editorial Verbo, 1972.

CONDORCET, Jean-Antoine-Nicolas de Caritat, Marquis. Escritos políticoconstitucionais. Campinas: Ed. UNICAMP, 2013.

DEFOE, Daniel. Robinson Crusoé. São Paulo: Abril, 1972.

DOSTOIÉVSKI, Fiódor. Uma história lamentável. Rio de Janeiro: Paz e Terra, 1996.

ESOPO. Fábulas. Porto Alegre: L\&PM, 2013.

FICHTE, Johann Gottlieb. Introdução à teoria do Estado. In: Os pensadores. São Paulo: Abril Cultural, 1980. p. 297-313.

FIELDING, Henry. Tom Jones. São Paulo: Nova Cultural, 2003.

GOETHE, Johann Wolfgang von. Fausto \& Werther. São Paulo: Nova Cultural, 2002. 
HEGEL, Georg Wilhelm Friedrich. Cursos de estética. 2. ed. São Paulo: EdUSP, 2001. v. 1.

HÖLDERLIN, Friedrich. Hipérion ou o eremita da Grécia. Lisboa: Assírio e Alvim, 1997.

HOMERO. Ilíada. 2. ed. São Paulo: Ediouro, 2009.

HUME, David. Investigação sobre o entendimento humano. São Paulo: Hedra, 2009.

KANT, Immanuel. Crítica da razão prática. Petrópolis: Vozes; Bragança Paulista: Editora Universitária São Francisco, 2017.

LA BRUYÈRE, Jean de. Caracteres. Ou costumes deste século. São Paulo: Escala, [s.d.].

LA ROCHEFOUCAULD, François de. Reflexões ou sentenças e máximas morais. São Paulo: Penguin Classics; Cia. das Letras, 2014.

MENANDRO. O misantropo. Rio de Janeiro: Ediouro, [s.d.].

RAMOS, Graciliano. Memórias do cárcere. 19. ed. Rio de Janeiro; São Paulo: Record, 1984. v. 1.

ROUSSEAU, Jean-Jacques. Os devaneios do caminhante solitário. Porto Alegre: L\&PM, 2010.

SAAVEDRA, Miguel de Cervantes. O engenhoso fidalgo D. Quixote de La Mancha. São Paulo: Ed. 24, 2002. 2 v.

SIN-LÉQI-UNNÍNNI. Epopeia de Gilgámesh. Belo Horizonte: Autêntica, 2018.

STENDHAL. O vermelho e o negro. Crônica do século XIX. 3. ed. São Paulo: Cosac Naify, 2015.

SÜSKIND, Patrick. O perfume. Rio de Janeiro; São Paulo: Record, [s.d.].

VICO, Giambattista. Princípios de uma ciência nova: acerca da natureza comum das nações. In: Os pensadores. 2. ed. São Paulo: Abril Cultural, 1979. p. 1-177.

VIEIRA, Padre Antônio. Sermões. Rio de Janeiro: Editora 3, 1974. v. 43. 